\title{
Evidensdagsordenens metamorfoser i dansk socialpolitik
}

\author{
Af Anne Mette Møller, ph.d.-stipendiat, Institut for Statskundskab, Københavns \\ Universitet
}

Idéen om evidensbaseret praksis har gennem to årtier sat sit præg på udviklingen af det sociale område. Med udgangspunkt i translationsteori bidrager artiklen med en analyse af, hvordan politiske eliteaktørers fortolkninger af evidensbaseret praksis har

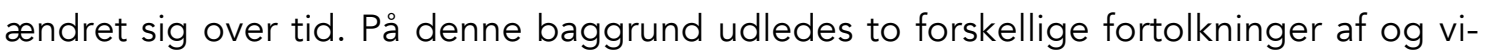
sioner for evidensbaseret praksis, der gør sig gældende blandt aktørerne i dag, kaldet hhv. 'refleksive organisationer' og 'data-drevet styring'.

Introduktion

Idéen om evidensbaseret politik og praksis har i løbet af de sidste to årtier bredt sig på tværs af landegrænser, fagområder og policy-kredse (Bhatti et al. 2006; Bohlin \& Sager 2011; Christensen and Krejsler 2016; Krogstrup 2011; Svanevie 2011). I Danmark har ordet 'evidens' sat sig spor i debatten om både sundhed og uddannelse, kriminalitetsforebyggelse, beskæftigelses- og socialpolitik. Idéen er grundlæggende, at indsatser på velfærdsområderne skal være baseret på den aktuelt bedste viden om, hvad der virker. Det vil føre til mere effektive indsatser, sparede udgifter til indsatser, som ikke har nogen effekt, eller i værste fald er direkte skadelige, større transparens i politiske og professionelle beslutningsprocesser og øget livskvalitet for borgerne (se fx Hede 2011; Konnerup 2011). Definitioner af evidensbaseret praksis tager ofte udgangspunkt i definitionen på evidensbaseret medicin (Sackett et al. 1996), hvorfra idéen stammer. Denne er af SFI Campbell ${ }^{1}$ er blevet oversat til: "En omhyggelig, udtrykkelig og kritisk brug af den aktuelt bedste viden, når der træffes beslutninger om andre menneskers velfærd”.

\footnotetext{
${ }^{1}$ SFI Campbell er en del af SFI - Det Nationale Forskningscenter for Velfærd og fungerer som den danske repræsentant for den internationale evidensorganisation The Campbell Collaboration (se fx Bhatti et al. 2006).
} 
Det er umiddelbart svært at være imod. Ikke desto mindre har 'kampen om evidens' (Krogstrup 2011) raset lige så længe, som begrebet har været anvendt. Det skyldes ikke mindst, at ovenstående definition åbner for utallige spørgsmål: Hvem bestemmer, hvad der er 'aktuelt bedste viden'? Hvordan identificerer og lokaliserer man denne viden? Hvad vil det sige at 'bruge' den? Hvilke 'beslutninger' er der tale om, og hvem træffer dem? Forskellige svar på disse spørgsmål har vidt forskellige implikationer for de involverede aktører. Efter mere end to årtiers intensiv debat i både akademiske, fagprofessionelle og policy-kredse hersker der derfor fortsat uklarhed og uenighed om, hvad evidensbaseret praksis er, hvad det indebærer for de involverede, og hvorvidt idealet overhovedet er realiserbart eller ønskeligt i praksis. Det gælder også på socialområdet. Samtidig kommer der fortsat nye politiske initiativer, der har til hensigt at fremme en evidensbaseret praksis. På denne baggrund stiller artiklen følgende spørgsmål: Hvilke fortolkninger af evidensbaseret praksis kan identificeres blandt politiske aktører på socialområdet i Danmark, hvordan har fortolkningerne ændret sig over tid og med hvilke begrundelser?

Artiklen er struktureret som følger: Først gives et kort overblik over evidensdagsordenens udvikling på socialområdet og dermed konteksten for analysen. Herefter præsenteres den teoretiske tilgang, som er funderet i et translations- eller oversættelsesteoretisk perspektiv, samt det empiriske grundlag, som består af kvalitative interview med politiske eliteaktører. Området for udsatte børn og unge er både i interviewene og $\mathrm{i}$ artiklen fremdraget som en illustrativ case, idet debatten og de politiske initiativer her har været særlig markante. Interviewpersonernes udsagn omhandler imidlertid i flere tilfælde hele det socialpolitiske felt. Det gælder således også analysen, hvoraf første del har et retrospektivt fokus, men anden del har et prospektivt fokus. Analysen viser overordnet, at evidensdebatten har haft en betydelig konceptuel (idé- og begrebsmæssig) indflydelse på feltet. Samtidig er der over årene sket en række forskydninger i idealerne for evidensbaseret praksis. Centrale aktører har revurderet deres positioner, og nye stemmer har meldt sig i debatten. På baggrund af analysen identificeres to aktuelle visioner for den fremtidige udvikling, kaldet hhv. refleksive organisationer og data-drevet styring.

\section{Evidensdagsordenen på socialområdet}

Debatten om evidens på det sociale område begyndte i slutningen af 1990'erne og tog fart i begyndelsen af nullerne. I 2002 blev Nordisk Campbell Center (senere SFI Campbell) etableret for at udbrede idéen om evidensbaseret praksis samt viden om effekterne af forskellige indsatser på socialområdet. En gruppe kommuner var allerede godt $\mathrm{i}$ gang med at importere og implementere evidensbaserede metoder på området for udsatte 
børn og unge, primært udviklet i USA. ${ }^{2}$ Disse manualbaserede programmer, som blev promoveret heftigt af Socialstyrelsen, udgjorde et markant alternativ til hidtidig praksis og var genstand for voldsom kritik fra fagprofessionelle kredse. Det næste årti rasede debatten om manualer kontra metodefrihed samt om evidenshierarkiet: Her fremhævede fremtrædende aktører randomiserede kontrollerede forsøg og statistisk metaanalyse som de eneste gyldige metoder til at opnå viden (om effekter), mens andre typer forskning og vidensformer i øvrigt - befandt sig længere nede på 'evidensstigen'. Som led i denne debat blev hidtidig praksis ofte karakteriseret som baseret på 'holdninger', 'mavefornemmelser' og 'synsninger' (se også Bhatti et al. 2006; Rieper \& Hansen 2007; Krogstrup 2011).

I 2013 etablerede Socialstyrelsen 'Metodeudbredelsesprogrammet' til 280 mio. kr., som havde til formål at intensivere udbredelsen af seks udvalgte metoder til landets kommuner. Samtidig lancerede man en samlet politik for udvikling og anvendelse af evidens (Socialstyrelsen 2013), hvor spørgsmålet 'virker det?' blev fulgt af to andre spørgsmål, nemlig: 'hvad koster det?' og 'hvordan implementeres det?'. De potentielle økonomiske gevinster ved evidensbaserede metoder var for alvor kommet på dagsordenen i 2012, hvor en konsulentrapport anslog, at implementeringen af fire specifikke metoder i arbejdet med udsatte børn og unge ville medføre besparelser på 2,5 mia. årligt (Rambøll 2012) ${ }^{3}$. Det økonomiske aspekt kom igen i fokus, da den daværende vicedirektør i Socialstyrelsen i 2015 gav et interview til Mandag Morgen med overskriften 'Milliarder bliver brugt i blinde' (Reiermann \& Andersen 2015). Rationalet var, at idet under $10 \%$ af de anvendte metoder i kommunerne er baseret på evidens, ved vi reelt ikke, om de øvrige indsatser virker. Interviewet affødte stærke reaktioner fra bl.a. KL (Adelskov 2015). KL havde, efter mange års fravær, meldt sig på banen tilbage i 2013 med det socialpolitiske udspil 'Investér før det sker'. Heri slås det fast, at "[k]ommunerne skal anvende virksomme og omkostningseffektive metoder. Det kræver, at kommunerne løbende efterspørger og selv opsøger og skaber ny viden, som de kan stille til rådighed for andre. Kommunerne skal systematisk dokumentere og evaluere, om de enkelte metoder og indsatser giver den forventede effekt." (KL 2013, 12). Samtidig fastholdt KL værdien af lokal metodeudvikling og erfaringsbaseret viden (Wiis 2015). Samme kurs findes i et nyere udspil om udsatte børn og unge (KL 2015).

Gennem alle årene har den til enhver tid siddende minister pointeret, at sociale indsatser skal baseres på viden om, hvad der virker (fx Ellemann 2015; Uddannelses- og Forskningsministeriet 2012). Aktuelt har dette udmøntet sig i en data- og analysestrategi for det socialpolitiske område. I juni 2016 udgav ministeriet for første gang Socialpolitisk redegørelse, som efter planen skal udkomme hvert år med henblik på at give overblik over områdets tilstand, identificere videnshuller og tilskynde anvendelsen af meto-

\footnotetext{
${ }^{2}$ Fx Multi-Systemisk Terapi (MST), De Utrolige År (DUÅ) og Parent Management Training-Oregon (PMTO) - ofte kaldet 'bogstavprogrammerne' grundet de hyppigt anvendte forkortelser. Der er fortsat debat om, hvorvidt der faktisk foreligger gyldig evidens for metodernes effekt. Ikke alle mener, at betegnelsen 'evidensbaseret' er fortjent.

${ }^{3}$ En konklusion, der blev anfægtet fra flere sider, herunder af forskere på SFI.
} 
der med dokumenterede effekter (Social- og Indenrigsministeriet 2016a; 2016b). I dette års satspuljeforhandlinger er der desuden afsat knap en halv mia. kroner til effektmåling og udbredelse af evidensbaserede sociale indsatser (Andersen 2017).

\section{Teoretisering og translation af policy-idéer}

Artiklens teoretiske perspektiv tager udgangspunkt i skandinavisk institutionalisme og begrebet translation eller oversættelse. Translationsbegrebet er koblet til metaforen om idéer, der rejser, og udtrykker det forhold, at en idé, koncept eller metode altid oversættes - dvs. fortolkes, omformes, redigeres og rekonstrueres - i den kontekst, den oversættes i (Czarniawska \& Sevón 1996; Røvik 2007; Sahlin \& Wedlin 2008; Waeraas \& Nielsen 2016). Evidensbaseret praksis forstås hermed ikke som et præcist begreb, men som en "løst koblet strøm af ideer, som aktører fortolker i overensstemmelse med deres overbevisninger og problemdefinitioner" (Johansson et al. 2015, 74, min oversættelse). Translationsperspektivet er tidligere anvendt i studier af, hvordan evidensdagsordenen er blevet oversat på socialområdet i Sverige (Johansson et al. 2015; Lundstrom \& Shanks 2013) samt på skoleområdet i Norge. I sidstnævnte sammenhæng er evidensbaseret praksis blevet karakteriseret som en 'masteridé' (Czarniawska \& Joerges 1996): En særlig magtfuld idé, der i en given tidsperiode har opnået høj gennemslagskraft og virker som et legitimerende narrativ for reformer på tværs af organisatoriske og nationale kontekster (Røvik \& Pettersen 2014).

Det ligger i translationsperspektivet, at en idé med tiden kan blive institutionaliseret, dvs. blive en integreret del af praksis. Hermed stilles der ikke længere spørgsmål ved dens grundlæggende antagelser og forudsætninger. Den 'oprindelige' idé kan være mere eller mindre genkendelig. I forlængelse heraf har nyere studier fremhævet, at translation og institutionalisering af idéer bedst kan forstås som kontinuerlige ikkelineære processer, der i princippet altid er uafsluttede og dermed åbne for forhandling og konflikt. En yderligere central pointe er, at disse processer finder sted simultant i den enkelte organisation og det brede organisationsfelt. Et organisationsfelt udgøres af organisationer, der er underlagt samme regulering og/eller er repræsenteret ved et fælles meningssystem - hvilket kan siges om det sociale område. Et felt kan være pluralistisk i den forstand, at selvom der er en fælles forståelse af visse aktiviteter, kan der herske stor uenighed om, hvordan disse aktiviteter bør udføres i praksis som følge af forskellige overbevisninger og rationaler (Nielsen et al. 2014).

For at komme institutionaliseringsprocessen nærmere kan det, som Nielsen et al. (2014) peger på, være relevant at indføre en analytisk skelnen mellem translation og teoretisering. Translation betegner her processer, hvorved en idé omsættes til praksis i specifikke organisatoriske kontekster, hvad Røvik (2007) ville kalde rekontekstualisering. Teoretisering er derimod primært en diskursiv aktivitet, hvor aktører i et felt udspecificerer de abstrakte kategorier, der er knyttet til en idé, samt udvikler normative fortolkninger og formulerer egne teorier om 'årsags-virkningsforhold' i relation til idéen 
(Greenwood et al. 2002; Nielsen et al. 2014). Teoretiseringen indebærer, at der udpeges en organisatorisk fiasko, som idéen er løsningen på, hvorved idéen opnår pragmatisk legitimitet. Herudover må idéen tilpasses herskende normative forskrifter inden for en given kontekst - eksempelvis professionel, økonomisk eller styringsmæssig - for derved at opnå moralsk legitimitet.

Teoretisering og translation skal ses som komplekse, sammenfiltrede og situerede praksisser, hvor interessenter - i form af eksempelvis politiske aktører, forskere, konsulenter og praktikere - kontinuerligt udveksler, forhandler og afprøver nye idéer (Nielsen et al. 2014, 169). Artiklen fokuserer på, hvordan evidensbaseret praksis er blevet teoretiseret af politiske aktører, og hvilke teoretiseringer der gør sig gældende i dag. Ovennævnte legitimitetsbegreber står centralt i analysen, som dermed stiller skarpt på ét aspekt af institutionaliseringsprocessen, mens de samtidige translationsprocesser, som finder sted i lokale organisatoriske kontekster ( $\mathrm{fx}$ kommuner og institutioner), ikke behandles nærmere.

\section{Metode og datagrundlag}

Metodologisk trækker artiklen på en fortolkende tilgang til studiet af forandringer i den offentlige sektor (Bevir et al. 2003; Bevir 2011). I overensstemmelse med translationsteorien betoner Bevir m.fl. betydningen af agency, herunder politiske aktørers aktive rolle $\mathrm{i}$ at forme, vedligeholde og forandre institutioner. Tanken er, at disse aktørers overbevisninger om, hvordan verden hænger sammen, har betydning for, hvilke løsninger de gør sig til fortalere for, og er en grundlæggende drivkraft for deres handlinger. Handlinger forstås som reaktioner på bestemte (ofte intersubjektive) problemopfattelser, snarere end 'objektive' fakta om verden.

Artiklens empiriske grundlag består af 10 kvalitative interview/samtaler med politiske eliteaktører, som er eller har været involveret $\mathrm{i}$ evidensdagsordenens udvikling $\mathrm{i}$ Danmark (jf. bilag 1). ${ }^{4}$ Politiske eliteaktører defineres som personer, der i kraft af deres strategiske placering i store eller på anden vis centrale organisationer eller bevægelser har mulighed for jævnligt og substantielt at påvirke udfaldet af politiske processer (Higley 2008). ${ }^{5}$ Definitionen omfatter både højt placerede politikere og embedsmænd, private aktører og mere eller mindre kendte ledere af fx fagforeninger, frivillige foreninger

\footnotetext{
${ }^{4}$ Det kan naturligvis diskuteres, i hvilket omfang interviewpersonerne kan siges at udgøre et tilstrækkeligt udsnit af de potentielt relevante aktører. Det vil altid være muligt at udvide kredsen, og analysen må derfor læses med forbehold for, at ikke alle aktører er repræsenteret på lige fod.

${ }^{5}$ De vigtigste organisationer i denne sammenhæng er Socialministeriet og herunder Socialstyrelsen, SFI Det Nationale Forskningscenter for Velfærd samt Nordisk Campbell Center, der siden blev en integreret del af SFI under navnet SFI Campbell. Hertil kommer KL, Socialchefforeningen (FSD), faglige organisationer som Dansk Socialrådgiverforening og Socialpædagogernes Landsforbund, professionshøjskolerne, der uddanner socialrådgivere og socialpædagoger, og private aktører som TrygFonden, der bidrager til at finansiere forskning og udvikling på bl.a. socialområdet og dermed også har en dagsordensættende funktion.
} 
eller (midlertidigt) politisk indflydelsesrige sociale bevægelser. ${ }^{6}$ Interviewene er gennemført med udgangspunkt i fælles overordnede temaer og spørgsmål og har en varighed af 40-140 min. Otte interview er optaget og transskriberet, mens der for de resterende to er taget udførlige noter under og efter samtalen. Analysen er yderligere informeret af relevante rapporter og policy-dokumenter, samtaler med akademiske eksperter, der har forsket i evidensdagsordenen, samt deltagelse i syv konferencer i årene 20062015, hvor evidensbegrebet har været til debat. ${ }^{7}$

I analysen er informanternes udsagn fortolket i relation til interaktionen med intervieweren og konteksten for deres tilblivelse (Järvinen \& Mik-Meyer 2005). Temaerne er fremkommet via en bevægelse mellem induktiv og deduktiv kodning med fokus på pragmatisk og moralsk legitimering, informanternes egne forklaringer på udviklingen (årsager og virkninger) samt fremtidsvisioner. Der gøres i vid udstrækning brug af interviewpersonernes egne begreber (Bevir et al. 2003, 13f).

Teoretiseringer af evidensbaseret praksis på socialområdet i Danmark

Analysen falder i to dele. Første del omhandler interviewpersonernes retrospektive fortolkninger af evidensdagsordenens udvikling. Anden del har et prospektivt fokus med udgangspunkt $\mathrm{i}$ interviewpersonernes aktuelle teoretiseringer af evidensbegrebet og dagsordenen på socialområdet.

Del I: Refleksioner over evidensdagsordenens udvikling

Langt de fleste interviewpersoner giver udtryk for, at socialområdet står over for en massiv udfordring $\mathrm{i}$ form af stigende udgifter kombineret med manglende (viden om) effekt af indsatserne. Hermed udpeges en klar organisatorisk fiasko. Den målrettede indsats for at udbrede evidensbaserede metoder på området for udsatte børn og unge ses i forlængelse heraf som et forsøg på at håndtere denne udfordring. Idéen om evidensbaseret praksis tilskrives herved en grundlæggende pragmatisk legitimitet. I tilbageblik opfattes den konkrete strategi imidlertid af mange interviewpersoner som utilstrækkelig eller ligefrem "desperat". Idéen om at udvælge og promovere et begrænset antal metoder - uden blik for de mange målgrupper, problemstillinger og aspekter af praksis, som

\footnotetext{
${ }^{6}$ I lyset af Higleys definition af politiske eliteaktører kan det bemærkes, at evidensdagsordenens fortalere ofte omtales som en 'bevægelse' eller 'movement (fx Bhatti, Hansen \& Rieper 2006; Greenhalgh m.fl. 2014).

${ }^{7}$ Disse tæller tre "Hvad virker?"-konferencer afholdt af SFI Campbell i 2006, 2007 og 2008, to konferencer om evidens og effektmåling arrangeret af SFI i hhv. 2012 og 2013 samt Dansk Evalueringsselskabs årsmøder i hhv. 2013 og 2015.
} 
ikke er omfattet af disse ${ }^{8}$ - beskrives af en interviewperson som "fantastisk" (i betydningen utrolig eller illusorisk). Strategien kritiseres af flere for at være baseret på en forsimplet forståelse af, hvad det indebærer at forandre praksis, og for at udtrykke en forestilling om, at det blot er et spørgsmål om tid, før alle problemstillinger, målgrupper og metoder er kortlagt, og man kan "trække løsninger ned fra hylderne" - en forestilling, som mange (men ikke alle) i dag ryster på hovedet af.

I tilbageblik problematiserer flere interviewpersoner den tilsyneladende manglende refleksion hos ministeriet og Socialstyrelsen over de reelle muligheder for og implikationer ved at "overføre" metoder fra én kontekst til en anden, primært fra en amerikansk til en dansk velfærdskontekst. Andre peger på, at mismatchet mellem de promoverede metoder og danske pædagogiske traditioner ikke blev taget alvorligt nok, og at den massive modstand kom bag på initiativtagerne. Endelig forholder mange sig kritisk til indsnævringen af evidensbegrebet til alene at omhandle spørgsmålet om effekt, herunder det massive fokus på evidenshierarkier og metoder, som bevirkede, at andre relevante forskningsspørgsmål og -tilgange med ét blev ugyldiggjort. Nogle ser SFI som ansvarlig for den daværende hårde linje, mens andre beskriver Socialstyrelsen som "evidensforelskede".

Der er ligeledes enighed blandt flere om, at den skarpe kritik af hidtidig praksis, som prægede debatten i begyndelsen, har været uproduktiv og bidraget til at skabe unødigt stærk modstand blandt professionerne. Flere beklager, at debatten gennem årene har skabt en falsk modstilling, hvor evidens fremstår som 'god viden', mens professionsfaglig ekspertise fremstår som 'dårlig viden'. Man har herved gravet grøfter og fremmedgjort professionerne i en grad, så selve ordet 'evidens' i dag står i vejen for dialog og udvikling. Det insisterende fokus på en snæver definition af evidens og udbredelsen af manualbaserede metoder har ifølge disse interviewpersoner blokeret mulighederne for at tilpasse forståelsen af evidensbaseret praksis til de herskende normative forskrifter i feltet. Dermed er det ikke lykkedes at skabe den nødvendige moralske legitimitet for idéen blandt fagprofessionelle, faglige organisationer, interesseorganisationer og forskere inden for socialt arbejde - og i nogen grad også kommunerne. Interviewpersonerne konstruerer hermed retrospektivt en fortælling med et klart årsagvirkningsforhold, når de argumenterer for nødvendigheden af at genoverveje betydningen af evidensbaseret praksis. I denne optik er det afgørende fremadrettet at inkludere professionel ekspertise i forståelsen af, hvad evidensbaseret praksis indebærer. Denne argumentation findes bl.a. hos Socialstyrelsens tidligere direktør, direktøren for SFI og lederen af SFI Campbell.

Andre interviewpersoner er enige $\mathrm{i}$ behovet for at nuancere evidensbegrebet, men peger på en anden årsag, nemlig erkendelsen af, at der aktuelt ikke findes tilstrækkeligt med evidensbaserede metoder, som man kan "tage ned fra hylderne". Derfor, forklarer interviewpersonerne, har man fra Socialministeriets og Socialstyrelsens side

\footnotetext{
${ }^{8}$ Metoderne er alle baseret på kognitive-behaviouristiske tilgange og målrettet børn og unge med primært udadreagerende adfærd, selvom nogle med tiden også er forsøgt anvendt over for børn med eksempelvis angst.
} 
været nødsaget til at nuancere begrebsapparatet og tale om evidens på flere niveauer. I denne optik stiller man ikke spørgsmål ved evidensbegrebets moralske legitimitet og problematiserer ej heller den implicitte udgrænsning af andre former for viden, herunder professionel ekspertise, som andre forholder sig kritisk til. Behovet for et ændret begrebsapparat er her snarere et pragmatisk/teknisk spørgsmål, idet man ikke vil bruge ordet 'evidensbaseret' om noget, der ikke lever op til de metodiske krav. I stedet må man opbygge et solidt evidensgrundlag "nedefra" med udgangspunkt i dokumentation af praksis, om muligt via kontrollerede forsøg, som man fortsat arbejder for at igangsætte. Denne anden nuancering består altså i en accept af, at det - for nuværende - er nødvendigt at arbejde med metoder på "alle niveauer af evidensstigen". Fokus er fortsat på dokumentation, udbredelse og implementering af 'så-vidt-muligt-evidensbaserede' metoder.

Kommunalt selvstyre og professionel metodefrihed

Interviewpersonerne oplever alle, at evidensdebatten med tiden har sat sig igennem $\mathrm{i}$ både kommuner og fagforeninger, og at der begge steder er sket en kolossal udvikling, omend billedet fortsat er broget. Blandt kommunerne ses nogle som frontløbere, der overhaler Socialstyrelsen indenom, mens andre halter bagud. Generelt oplever interviewpersonerne dog et stigende engagement fra kommunernes side. Én beskriver kommunerne som delt i to "skoler": Nogle investerer i socialområdet, herunder evidensbaserede metoder, hvilket begrundes med både faglige, etiske og langsigtede økonomiske hensyn. ${ }^{9}$ Modsat anses andre kommuner for fortsat at betragte det sociale område som en ren udgiftspost; et "sort hul", hvor målet primært er at holde borgerne såvel som udgifterne i ro.

KL har i dag placeret sig solidt på linje med de førstnævnte kommuner. Det socialpolitiske udspil Invester før det sker fra 2013 beskrives således af interviewpersonen fra KL som KL's endelige opgør med 'de tusind blomster' i dansk socialpolitik og den hidtil stærke - men i princippet unødvendige - kobling mellem det kommunale selvstyre og den fagprofessionelle metodefrihed (dvs. autonomien til at vælge med hvilke midler et givent mål skal nås). Den pragmatiske legitimitet afspejles i udspillets betoning af investeringslogik og omkostningseffektive metoder. Samtidig søges den moralske legitimitet omkring evidensdagsordenen styrket ved at indføre et skel mellem to forskellige normative forskrifter, der længe er blevet opfattet som hørende sammen: Evidensdagsordenen udgør ganske vist et opgør med de fagprofessionelles metodefrihed, men man kan forsat stå fast på kommunernes autonomi.

I forhold til fagforeningerne er oplevelserne delte. Mange interviewpersoner beskriver, hvordan de professionelle fagforeninger gennem årene har udvist en "helt utrolig stærk" og vedholdende modstand mod evidensdagsordenen. Mens nogle udtrykker

\footnotetext{
${ }^{9}$ Som eksempel nævnes fire kommuner og en regions samarbejde om at etablere og drive den selvejende institution Metodecentret, som blandt andet implementerer og kvalitetssikrer evidensbaserede programmer.
} 
en vis forståelse for, at evidensbaseret praksis kan stride imod professionelle normer, karakteriseres modstanden samtidig som både "umoden" og "trættende", ligesom den af flere anses for at være baseret på en falsk modstilling mellem systematik og førnævnte metodefrihed. Flere konstaterer dog også med tilfredshed, at de i dag oplever en positiv bevægelse blandt professionerne og de faglige organisationer. Én oplever således, at evidensbegrebet er gået fra at være "totalt afkoblet" og omgærdet af modstand til at være en integreret del af samtalen på uddannelsessteder og i praksis.

Samtidig noterer mange sig, at flere fagforeninger også er gået proaktivt ind i debatten. Det gælder fx Dansk Socialrådgiverforening, hvis næstformand beskriver evidensdebatten som "et spejl der blev holdt op foran os: Hvad er det egentlig, I gør?". Evidensdagsordenen udgjorde med sine beskrivelser af hidtidig praksis som baseret på 'synsninger' og 'mavefornemmelser' en direkte udfordring af socialrådgivernes professionalisme, hvilket ifølge næstformanden fik "blodet til at koge". Man valgte dog hurtigt en konstruktiv tilgang, og i dag ser man foreningens positionering i forhold til 'vidensdagsordenen' som afgørende for udviklingen af både socialområdet og socialrådgiverprofessionen selv (Barkholt 2014; 2015). Retrospektivt ses det dermed som positivt, at evidensdebatten har krævet gentænkning af socialrådgiverprofessionens kernefaglighed og kernekompetencer. Samtidig fremhæves det også som understøttende for udviklingen, at andre aktører på området med tiden er blevet "mindre firkantede".

Her kan altså identificeres en bevægelse, hvor tidligere kritikere i form af fagforeningerne nu bevæger sig aktivt ind i forhandlingerne om, hvad idéen om evidensbaseret praksis indebærer. Samtidig har KL efter flere års tilbageholdenhed valgt at positionere sig klart. Dermed bidrager flere til den fortsatte teoretisering af idéen.

De evidensbaserede programmer som katalysator

I lyset af de relativt kritiske refleksioner er det interessant, at samtlige interviewpersoner ser det massive fokus på udbredelsen af evidensprogrammerne som en afgørende katalysator, der har banet vejen for mere nuancerede og ambitiøse strategier. Evidensprogrammerne har ifølge mange bidraget til at indføre nogle centrale, men hidtil relativt upåagtede, begreber i praksis, herunder systematik, eksplicit teoretisk forankring, tidsbegrænsede indsatser med klare mål, en forventning om målbare resultater og systematisk opfølgning. De har samtidig ifølge flere givet anledning til en konfrontation med den dominerende diskurs inden for socialt arbejde, hvor virkningen af en indsats ses som resultat af den unikke relation mellem den fagprofessionelle og borgeren. Som modpol hertil har de evidensbaserede metoder sat fokus på mønstre og ligheder på tværs af problemer, tilgange og virkninger i de individuelle sager, dvs. generaliseringspotentialet i det sociale arbejde.

Denne metateoretiske ny-orientering anses sammen med de øvrige elementer, programmerne har bragt med sig, som afgørende for udviklingen af fremtidig praksis, hvor evnen til forholdsvist detaljeret at kunne beskrive og dokumentere en given meto- 
de betones som særligt central. Nogle pointerer i den forbindelse, at de evidensbaserede metoder langt fra blot er simple opskrifter: Implementeringen af dem kræver certificering, supervision og samarbejde på tværs af professionelle og organisatoriske grænser. Dermed bidrager de til at skabe nye vaner og præge opgaveløsningen i bredere forstand. I dag argumenterer flere for, at disse elementer ikke nødvendigvis skal være bundet op på manualbaserede programmer, men bør udgøre en integreret del af praksis i generel forstand. En af interviewpersonerne taler om 'generation 2' i evidensdagsordenen: Mens generation 1 var karakteriseret ved import og udbredelse af programmer, som mentes at virke på tværs af lokale og nationale kontekster, er generation 2 kendetegnet ved afprøvning og evaluering af metoder, som er udviklet på baggrund af forskningsbaseret viden om virksomme elementer ('core components') under hensyn til den nationale og lokale kontekst. Målet er dermed produktion af lokal eller praksisbaseret evidens, frem for implementering af 'færdige' programmer baseret på global evidens (systematiske forskningsoversigter og metaevalueringer). Det vender vi tilbage til.

Fra evidensbaserede metoder til vidensbaseret praksis?

Første del af analysen viser, at der i høj grad er skabt pragmatisk legitimitet omkring evidensdagsordenen, idet udlægningen af socialområdet som en 'organisatorisk fiasko' stort set deles af alle. Omvendt er det kun i nogen grad lykkedes at skabe moralsk legitimitet på tværs af det organisatoriske felt. Blandt de politiske aktører kan der spores flere forsøg på at tilpasse idéen om evidensbaseret praksis til herskende normative forskrifter blandt kritikerne - et eksempel herpå er KL's forsøg på at adskille spørgsmålet om de fagprofessionelles metodefrihed fra spørgsmålet om det kommunale selvstyre, således at man kan stå fast på det sidste uden at forsvare det første. Flere fremhæver vigtigheden af at tage udgangspunkt i praksis og erfaringsbaseret viden med henblik på at skabe "praksisbaseret evidens" frem for fortsat at fokusere på de udskældte manualbasererede metoder.

I forlængelse heraf foretrækker flertallet af interviewpersonerne i dag at tale om 'vidensbaseret praksis' frem for evidens; en bevægelse der også afspejles i organisationernes formelle kommunikation: SFI afholdt i 2013 en konference med titlen 'Det svære evidensbegreb ${ }^{\prime 10}$. Året efter argumenterede afdelingslederen af SFI Campbell for at skelne mellem 'effekt' og 'evidens' og for at bruge ordet 'vidensbasering' frem for 'evidensbasering' (Deding et al. 2014). I foråret 2015 var ordet 'evidens' stort set ikke længere at finde på Socialstyrelsens hjemmeside: De evidensbaserede programmer omtales nu som 'dokumenterede metoder'. I 2016 lancerede SFI og Socialstyrelsen i fællesskab et projekt med det formål at udvikle metoder til dokumentation af 'lovende praksis', KL og SFI udgav rapporten Vidensbasering af socialt arbejde med syv hand-

\footnotetext{
${ }^{10}$ Konferencen blev afholdt 26.2.2013; se også http://www.sfi.dk/nyt/nyheder/artikler/evidens-er-mereend-effektmaaling/
} 
lingsrettede anbefalinger til kommunerne ${ }^{11}$, og overskriften for en nylig konference på området var 'Vidensbaseret socialpolitik og -praksis' (Socialstyrelsen, UCL og KORA, 2015). Overordnet kan der altså identificeres en klar bevægelse væk fra et snævert evidensbegreb mod et bredere vidensbegreb, som i hvert fald delvist er motiveret af oplevelsen af evidensbegrebets manglende moralske legitimitet.

\section{Del 2: Aktuelle forståelser og visioner for evidensdagsordenen}

En af kilderne til uenighed om den fortsatte udvikling på området er, hvilken status den fagprofessionelle ekspertise bør tildeles. Flere ser det som afgørende, at fagprofessionel ekspertise ikke fortsat negligeres, men i stedet integreres $i$ et bredt vidensbegreb, hvor den fremstår som en væsentlig og ligeværdig form for viden. Det kræver et opgør med årtiers mistro og talen-ned-til professionerne og en genetablering af både tillid og selvtillid. Ifølge den nuværende leder af SFI Campbell indebærer visionen dermed, "at vi begynder at tro på vores egne evner og på vores professioner, men baseret på viden som også kommer fra forskningen." Disse interviewpersoner understreger dog samtidig, at de taler om reel fagprofessionel ekspertise, baseret på faglig viden og erfaring - ikke lægmandsintuition eller de førnævnte 'synsninger' og 'mavefornemmelser'. ${ }^{12}$ Samtidig udtrykker de tvivl om, i hvilket omfang de fagprofessionelle, givet deres aktuelle uddannelse, erfaringsgrundlag og arbejdsbetingelser, aktuelt kan honorere dette vidensideal.

Dermed ser flere interviewpersoner (gen-)opbygningen af analytiske kompetencer og faglig nysgerrighed som centralt i en fremadrettet indsats. Én nævner "hverdagseksperimenter" og en anden "mikro-forskningsprojekter" som midler, der kan stimulere til faglig nysgerrighed og interesse for virkningerne af ens egne metoder. Tanken er her, at refleksion over resultaterne af egen praksis er et nødvendigt første skridt henimod at interessere sig for eksterne forskningsresultater og finde dem meningsfulde. Faglig ledelse bliver et nøgleord, hvor opgaven er at orkestrere systematisk vidensarbejde og kollektiv refleksion: "(...) det bliver en del af en ledelsesdiskussion og en del af at tænke i velfærdsledelse - at du også som leder i en forvaltning sætter rammerne for, at dine medarbejdere faktisk kan arbejde på denne her måde, altså at du forventer af dem, at de er refleksive", som lederen af SFI Campbell udtrykker det.

Visionen beskrives med begreber som 'evidensbaseret kultur', 'vidensbaseret praksis', 'refleksiv praksis' og 'lærende organisationer'. Alle kan ses som betegnelser for en teoretisering af evidensbaseret praksis, hvor systematik og kollektiv refleksiv

\footnotetext{
${ }^{11}$ De lyder: 1. Opstil en forandringsteori, 2. Dokumentér det vigtigste, 3. Følg systematisk op, 4. Lad den faglige refleksion være drivende, 5. Vær skarp på rollefordelingen, 6. Stil krav til videnskvalitet og 7. Opsøg og del viden.

${ }^{12}$ Flere refererer her til den akademiske litteratur om intuition og professionel ekspertise, eksempelvis Dreyfus \& Dreyfus' læringsmodel (1986) samt Daniel Kahnemans bestseller ”At tænke hurtigt og langsomt" (2014).
} 
dialog på grundlag af lokale data (dokumentation af indsatsen og måling af effekter for borgeren) fremstår som afgørende elementer. Vejen hertil italesættes som et langt sejt træk, som indebærer grundlæggende ændringer af professions- og organisationskulturer. Mange drager sammenligninger med sundhedsområdet som et forbillede, hvor der er større interaktion mellem forskning og praksis. Professionsuddannelserne anses ligeledes for at være centrale medspillere i forhold til at uddanne nye generationer af praktikere med sans for evidens. Det fremhæves samtidig, at opgaven med at omsætte data og forskningsresultater ikke skal løses af den enkelte, men ledelsesmæssigt og organisatorisk, eksempelvis via "knowledge brokers" (vidensmæglere), der formidler viden mellem forskning og praksis. Hvordan det konkret skal foregå, fremlægges som et åbent og presserende - spørgsmål.

Mens nogle ser denne kapacitetsopbygning som et centralt omdrejningspunkt for udviklingen af en refleksiv organisatorisk praksis, er andre imidlertid mere optaget af at fremme en centraliseret vidensopbygning på grundlag af solide data om effekter, implementering og omkostninger ved metoder, såvel som viden om målgrupper og udbredelsen af sociale problemer. Ambitionen er først og fremmest at opnå en bedre styring på området ved at aggregere data på nationalt niveau. Lokalt vil det give kommunale beslutningstagere mulighed for at prioritere i tilbudsviften; centralt vil det muliggøre sammenligning af kommunernes performance og udstilling af gode eksempler til efterfølgelse. Denne anden vision har mindre fokus på professions- og organisationsudvikling og mere fokus på udvikling af eksempelvis sammenhængende it-systemer, som muliggør en ensartet opsamling af data. Som én konstaterer i en halvt optimistisk, halvt ironisk tone, burde dette være muligt $\mathrm{i}$ et land, hvis samlede befolkningstal er mindre end New York Citys. Ambitionen hindres imidlertid af strukturelle barrierer og politiske interesser hos hhv. staten, kommunerne/KL, professionerne/de faglige organisationer (og kritiske forskere). Mens nogle ser disse politiske kampe som et naturligt vilkår, er andre umådelig trætte af de evindelige "ideologiske diskussioner", som forhindrer udviklingen. "Just do it!", lyder det klare budskab fra en af interviewpersonerne: Mål på effekten af jeres indsatser, så vi få opbygget et solidt vidensgrundlag. Det er ikke så svært.

Djævlen ligger i data

Over for visionen om den nye refleksive organisation, hvor data gøres til genstand for orkestreret refleksion som en integreret del af den fagprofessionelle praksis, står altså en vision om data-drevet styring. Denne vision tager udgangspunkt $\mathrm{i}$, hvad vi kan kalde det databaserede vidensbegreb. På den ene side er der tale om en udvidelse af det oprindeligt snævre evidensbegreb med fokus på RCT-studier, men 'viden' fremstår fortsat som lig med solide data og dermed som et alternativ til fagprofessionel erfaringsbaseret viden og ekspertise. Evidenshierarkiet er dermed fortsat referencerammen i forhold til at vurdere, hvilken viden der er mest relevant. Med andre ord er viden lig med data, og 
data er lig med bedre styring, som igen er lig med bedre kvalitet for færre midler. Dette står i kontrast til den førnævnte forståelse, hvor man så at sige har "lagt evidensstigen ned" og advokerer for, at forskellige vidensformer har relevans i forskellige sammenhænge.

I forlængelse heraf er det interessant, at den tidligere vicedirektør i Socialstyrelsen pointerer behovet for at skelne mellem evidensbaserede metoder og evidensbaseret praksis: Evidensbaseret praksis består $\mathrm{i}$ at integrere den aktuelt bedste viden (evidens) med borgerens præferencer og omfatter ikke nødvendigvis anvendelsen af bestemte metoder. Evidensbaseret praksis kraver dermed professionel dømmekraft frem for at underminere denne (et argument, der også findes hos fortalere for evidensbaseret medicin, se Sackett et al. 1996, og i forskningen om evidensbaseret praksis på socialområdet, bl.a. Olsson 2007; Gambrill 2008; van der Zwet et al. 2016). Blandt interviewpersonerne har mange imidlertid primært fokus på evidensbaserede metoder, blot nu med et 'bottom-up'-perspektiv på produktionen af evidens, mens et mindretal også har fokus på, hvordan man kan understøtte (e)vidensbaseret praksis i bredere forstand.

Blandt de sidstnævnte udtrykker flere bekymring over en strategi, som primært handler om at "skrue op for data". Én taler om "data-djævlen", der har fået tag i Socialministeriet, og flere beskriver en udvikling, hvor socialfagligheden gennem årene er blevet nedprioriteret, så der med deres øjne i dag stort set ikke sidder nogen i departementet med dybdegående socialfaglig viden og kendskab til området. Oprettelsen af en data- og analysesøjle i departementet ses som endnu et skridt i denne retning. Enkelte udtrykker bekymring for, at de øgede krav til data og dokumentation vil vise sig ødelæggende for det momentum, som de oplever, at 'vidensdagsordenen' endelig har opnået $\mathrm{i}$ kommunerne og de faglige organisationer.

Her er det værd at bemærke, at fokus på data ikke i sig selv ses som problematisk. Fortalerne for lokal kapacitetsopbygning understreger, at man i bestræbelserne på at genetablere den fagprofessionelle ekspertises status ikke må falde tilbage til tidligere tiders 'holdningsbaserede' praksis: Babyen - forstået som opmærksomhed på data og erkendelsen af at "noget viden er bedre end anden" - skal blive i badekarret! Uenigheden handler om omfanget og karakteren af data, herunder hvem der skal bruge den og hvordan. Skal den primært tjene et styringsformål eller skal den først og fremmest bruges til lokal refleksion? I hvor høj grad er der behov for sammenlignelighed på tværs, eventuelt på bekostning af anvendeligheden lokalt? Hvor meget og hvilken dokumentation er der behov for? Hvorvidt kan effektmåling integreres i den daglige praksis? Djævlen ligger som bekendt i detaljen - i dette tilfælde i dokumentationens omfang og karakter som henholdsvis overordnet eller underordnet fagprofessionel refleksion og ekspertise. 


\section{To aktuelle teoretiseringer}

Overordnet set har idéen om evidensbaseret praksis i dag vundet bred pragmatisk legitimitet. Fortællingen om den hidtidige udvikling på socialområdet med 'ustyrlige' udgifter og manglende dokumentation for indsatsernes effekt fremstår som en bredt anerkendt organisatorisk fiasko. Det har givet anledning til at stille spørgsmål ved eksisterende normer for professionalisme, styring og forvaltning af området, som alle politiske aktører må forholde sig til. Idéen om evidensbaseret praksis er ét blandt flere svar. Analysen viser imidlertid, at forståelserne af evidensbaseret praksis har ændret sig over tid, og at flere aktører har revurderet deres positioner, mens andre er trådt ind i kampen. Der kan i dag identificeres mindst to forskellige teoretiseringer, som til dels udspringer af aktørernes forskellige konstruktioner af årsager til den hidtidige udvikling og nødvendige justering.

Flere udpeger de fagprofessionelles og kommunernes reaktioner på evidensdagsordenens 'generation 1' og det 'mekaniske verdensbillede', disse initiativer repræsenterede, som årsag til behovet for en ny tilgang. Én analyse lyder således, at evidensdagsordenen har lidt under manglende moralsk legitimitet, idet de tidlige teoretiseringer ikke var kompatible med herskende normer og forskrifter i feltet, dels i forhold til kommunernes og de fagprofessionelles autonomi, dels i synet på professionel ekspertise og erfaringsbaseret viden som relevante vidensformer for socialt arbejde. Det har ført til fremmedgørelse og manglende samarbejdsvilje fra professionernes side, og en fortsat negligering af disse vidensformer vil føre til dårligere kvalitet. Mens ingen argumenterer for, at man bør vende tilbage til idealerne om de 'tusind blomster' og ubetinget metodefrihed, anser flere det således for bydende nødvendigt fremadrettet at inkludere professionel ekspertise, erfaring og lokal metodeudvikling i ideen om (e)vidensbaseret praksis. Virkemidlerne er faglig ledelse og kollektiv refleksion over egen praksis med udgangspunkt i lokale data.

Der findes imidlertid også en anden analyse. Her stilles ikke spørgsmål ved evidensideens moralske legitimitet; i stedet udpeges manglen på evidensbaserede metoder som det grundlæggende problem i forhold til den fremadrettede udvikling. En ny teoretisering kræver således også i denne optik et mere nuanceret evidensbegreb, men her i form af en accept af, at man må bevæge sig ned ad evidensstigen og acceptere viden på "lavere niveauer". Her findes fortsat en klar rangordning af vidensformer. Bevægelsen består i at nedtone fokus på den globale forskningsbaserede evidens til fordel for produktion af lokal praksisbaseret evidens, som kan danne grundlag for en informeret styring af området. Overordnet tegner der sig dermed et billede af to forskellige teoretiseringer, jf. tabel 1 (se næste side).

Det bemærkes, at der her er tale om en analytisk udkrystallisering af positioner, som ikke entydigt kan kobles til de forskellige aktører. Nogle aktører ser de to tilgange som hinandens forudsætninger, dog med forskellig vægt; mens der for andre er tale om væsensforskellige projekter. I den første teoretisering, kaldet refleksive organisationer, står lokal kapacitetsopbygning, eksperimenter og refleksion centralt. Den anden, kaldet 
data-drevet styring, har et overordnet policy-fokus, hvor evidensbegrebet er tæt koblet til ideen om resultatbaseret styring. Begge udtrykker en glidning i fokus fra spredning og implementering af manualbaserede metoder, baseret på global forskningsbaseret evidens, til produktion af lokal praksisbaseret evidens i form af dokumentation og evaluering af effekt, implementering og omkostningseffektivitet. Dermed har udvikling og afprøvning af 'hjemmedyrkede' metoder fundet plads i begge teoretiseringer. Samtidig er ordet 'evidens' stort set afløst af 'viden', 'data' eller 'dokumentation'. Ingen af teoretiseringerne omfatter den autonome 'evidensbaserede praktiker', som er omdrejningspunktet i den oprindelige definition af evidensbaseret medicin, jf. ovenfor (se også Sackett et al. 1996). Mens data-drevet styring har et klart fokus på evidensbaserede metoder, ligger refleksive organisationer tættere på nogle af de alternative modeller for forskningsinformeret praksis, som findes i litteraturen om socialt arbejde, kaldet eksempelvis 'refleksiv professionalisme' (Otto et al. 2009) og 'organisatorisk excellence' (Nutley et al. 2007; Walter et al. 2004). Førstnævnte fremhæver forskningens rolle som et baggrundstæppe for den fagprofessionelles refleksive praksis. Den anden har fokus på organisatorisk forankrede partnerskaber mellem velfærdsorganisationer og forskningsinstitutioner, hvor eksperimenteren og innovation danner grobund for forskningsinformeret udvikling af praksis.

\begin{tabular}{|c|c|c|}
\hline & Refleksive organisationer & Data-drevet styring \\
\hline Fokus & $\begin{array}{l}\text { Decentraliseret (data anvendes lo- } \\
\text { kalt) }\end{array}$ & Centraliseret (data anvendes nationalt) \\
\hline Vision & $\begin{array}{l}\text { Fagligt nysgerrige og opsøgende } \\
\text { praktikere og organisationer, der } \\
\text { eksperimenterer med udvikling og } \\
\text { afprøvning af metoder med inspira- } \\
\text { tion fra forskning samt egne og an- } \\
\text { dres erfaringer, "orkestreret refleksi- } \\
\text { on" }\end{array}$ & $\begin{array}{l}\text { Komplet viden om omfang og udbre- } \\
\text { delse af sociale problemer samt effek- } \\
\text { ter og omkostninger ved indsatser, } \\
\text { muliggør data-drevet styring, bench- } \\
\text { marking, prioritering, mv. }\end{array}$ \\
\hline Strategi & $\begin{array}{l}\text { Lokal kapacitetsopbygning, fokus } \\
\text { på faglig ledelse som understøtter } \\
\text { professionel ekspertise, udvikling af } \\
\text { redskaber til progressionsmåling, } \\
\text { dokumentation af praksis med hen- } \\
\text { blik på lokal refleksion }\end{array}$ & $\begin{array}{l}\text { National kapacitetsopbygning med } \\
\text { fokus på analytiske og statistiske kom- } \\
\text { petencer, udvikling af dokumentations- } \\
\text { systemer til national indsamling og } \\
\text { analyse af data med henblik på styring }\end{array}$ \\
\hline Trussel & $\begin{array}{l}\text { "Data-djævlen": Øgede krav til do- } \\
\text { kumentation kan ødelægge enga- } \\
\text { gementet blandt praktikere, såfremt } \\
\text { styringshensyn på nationalt niveau } \\
\text { trumfer hensyn til lokal anvendelig- } \\
\text { hed }\end{array}$ & $\begin{array}{l}\text { "Umoden opposition": Manglende } \\
\text { engagement fra kommuner og/eller } \\
\text { fagprofessionelle i at udvikle og im- } \\
\text { plementere nationale dokumentations- } \\
\text { systemer kan hindre systematisk ind- } \\
\text { samling af solid viden }\end{array}$ \\
\hline $\begin{array}{l}\text { Idealmodel/ } \\
\text { nøgleord }\end{array}$ & $\begin{array}{l}\text { Vidensbaseret praksis, refleksiv pro- } \\
\text { fessionalisme, lærende organisatio- } \\
\text { ner }\end{array}$ & $\begin{array}{l}\text { Evidensbaserede metoder, resultatba- } \\
\text { seret/ data-drevet styring }\end{array}$ \\
\hline
\end{tabular}

Tabel 1. To aktuelle teoretiseringer af evidensbaseret praksis på socialområdet 


\section{Konklusion}

Analysen viser, at ideen om evidensbaseret praksis har fået væsentlig indflydelse på socialområdet, både $\mathrm{i}$ form af implementering af specifikke metoder og via begreber, der i dag udgør en fast del af ordforrådet og visionerne blandt politiske aktører. Omvendt har rejsen gennem socialområdet og dansk forvaltningstradition, hvor mange stemmer gør sig gældende, også haft markant indflydelse på ideen. Aktuelt fremstår den $i$ to teoretiseringer, som vægter henholdsvis refleksive organisationer og data-drevet styring. I overensstemmelse med tidligere studier peger analysen på, at teoretisering såvel som translation ikke blot skal ses som tidlige stadier i en institutionaliseringsproces, men som kontinuerlige situerede praksisser, der kan omfatte mange forskellige aktører, og som løbende bidrager til forandring såvel som vedligeholdelse (Nielsen et al. 2014).

Forhandlingerne handler i dag ikke længere om, hvorvidt man er for eller imod, at evidens skal spille en rolle på socialområdet, men snarere om, hvor bredt eller snævert man definerer 'evidens' (eller 'viden'), og ikke mindst hvordan man forestiller sig anvendelsen heraf. Uenighederne går først og fremmest på, hvordan man rent praktisk udformer evalueringer, dokumentationssystemer og progressionsmålinger, og hvilke hensyn disse bør understøtte. Dermed er i hvert fald nogle af de kontroversielle spørgsmål, som tidligere har præget debatten, gledet i baggrunden: De færreste stiller i dag spørgsmål ved, hvorvidt man overhovedet kan eller bør måle (effekterne af) sociale indsatser, hvilke metoder der er relevante (når det gælder effektmåling), eller hvem der definerer, hvad der er en ønskelig effekt - spørgsmål, der i høj grad prægede debatten i de tidlige år.

På baggrund af de hidtidige erfaringer betragtes kommunerne og fagforeningerne i dag som helt nødvendige medspillere, der dog samtidig har et ansvar for at bidrage konstruktivt til den videre udvikling. Imidlertid anses flertallet af de fagprofessionelle for ikke at være tilstrækkeligt analytisk kompetente. Dermed bliver udviklingen af en 'vidensbaseret praksis' først og fremmest en organisatorisk og ledelsesmæssig opgave, hvor det primære ansvar placeres enten på det kommunale eller statslige niveau, mens den individuelle og relativt autonome 'evidensbaserede praktiker', som på egen hånd vurderer og integrerer forskning i sin praksis, glimrer ved sit fravær. Skyttegravskrigen mellem manualer og metodefrihed ser dermed ud til at være et overstået kapitel, som i dag er afløst af uenighed om, hvilken rolle dokumentation og (effekt-)måling af socialt arbejde konkret kan og bør spille i praksis. Kampen om evidens er stilnet af, men har samtidig fundet nye slagmarker. 
Litteratur

Adelskov, T. (2015). Kronik: Mere forskning - tak! . KL, [online]. Available at: http://www.kl.dk/Menu---fallback/Kronik-Mere-forskning--tak-id174319/ [Accessed 14 Sep. 2016].

Andersen, M. V. P. (2017). Nu skal effekten af sociale indsatser dokumenteres. Altinget,[online]. Available at: http://www.altinget.dk/artikel/153941-nu-skaleffekten-af-sociale-indsatser-dokumenteres [Accessed 23 Jan. 2017].

Barkholt, N. C. (2015). Vidensbro og vidensinfrastruktur - oplæg til refleksion om vidensbasering af socialt arbejde. Social Kritik, vol. 271(141), pp. 49-59.

Barkholt, N. C. (2014). Vidensbasering af socialt arbejde $i$ år 2024. [blog], Niels Christian Barkholt. Available at:

https://ncbarkholt.wordpress.com/2014/04/05/vidensbasering-af-socialt-arbejdei-2024/ [Accessed 23 May 2017].

Bevir, M. (2011). Interpretive Theory. In: M. Bevir, ed., The SAGE Handbook of Governance. Los Angeles: SAGE, Los Angeles, pp. 51-64.

Bevir, M., Rhodes, R. A. W. and Weller, P. (2003). Traditions of governance: Interpreting the changing role of the public sector. Public Administration, vol. 81, pp. 117.

Bhatti, Y., Hansen, H. F. and Rieper, O. (2006). Evidensbevaegelsens udvikling, organisering og arbejdsform: En kortloegningsrapport [online] København: AKF-Forlaget. Available at: http://curis.ku.dk/ws/files/15320254/evidens.pdf [Accessed 23 May 2017].

Bohlin, I. and Sager, M. (2011). Evidensens många ansikten: evidensbaserad praktik $i$ praktiken. Lund: Arkiv.

Christensen, S. and Krejsler, J. B. (2016). Evidens - kampen om viden der virker, Padagogisk Udviklings Fond, PUF's skriftserie, $n r$. 2. København: FOA.

Czarniawska, B. and Joerges, B. (1996). Travels of Ideas. In: B. Czarniawska, and G. Sevón, ed., Translating Organizational Change, Berlin; Boston: De Gruyter, pp. 13-49.

Czarniawska, B., Sevón, G., eds. (1996). Translating Organizational Change. Berlin, Boston: De Gruyter.

Deding, M., Hansen, H., Jakobsen, T. B. (2014). Efter evidens kommer viden. Danske Kommuner, [online]. Available at: http://www.danskekommuner.dk/Debat/Active/Efter-evidens-kommer-viden/ [Accessed 15 May 2015].

Ellemann, K. (2015). Sociale indsatser mangler evidens. Altinget, [online]. Availabe at: http://www.altinget.dk/social/artikel/karen-ellemann-sociale-indsatser-manglerevidens [Accessed 5 Aug. 2016].

Gambrill, E. (2008). Evidence-Based (Informed) Macro Practice: Process and Philosophy. Journal of Evidence-Based Social Work, vol. 5, pp. 423-452.

Greenhalgh, T., Howick, J., Maskrey, N. (2014). Evidence Based Medicine: A Movement in Crisis?. BMJ: British Medical Journal, 348, (Jun 13 4) G3725.

Greenwood, R., Suddaby, R., Hinings, C. R. (2002). Theorizing change: The role of professional associations in the transformation of institutionalized fields. Academy of Management Journal, vol. 45, pp. 58-80. 
Hede, A. (2011). Kan viden trimme velfærdsstaten? Samfundsøkonomen, vol. 1, pp. 5358.

Higley, P. (2008). Elite Theory in Political Sociology. Presented at the IPSA International Conference, Montreal.

Järvinen, M. and Mik-Meyer, N., ed. (2005). Kvalitative metoder i et interaktionistisk perspektiv. Interview, observationer og dokumenter, 1. udgave. København: Hans Reitzels Forlag.

Johansson, K., Denvall, V. and Vedung, E. (2015). After the NPM Wave. EvidenceBased Practice and the Vanishing Client. Scandinavian Journal of Public Administration, vol. 19, pp. 69-88.

KL. (2013). Investér før det sker - et debatoplaeg om fremtidens socialpolitik. København: KL.

KL. (2015). De udsatte børn - fremtiden er deres. KL-udspil om udsatte børn og unge. København: KL.

Konnerup, M. (2011). Redaktionelt forord. Samfundsøkonomen, pp. 3-4.

Krogstrup, H. K. (2011). Kampen om evidens. København: Hans Reitzels Forlag.

Lundstrom, T. and Shanks, E. (2013). Hård yta men mjukt innanmäte. Om hur chefer inom den sociala barnavården översätter evidensbaserat socialt arbete till lokal praktik. Socialvetenskaplig tidskrift, vol. 2, pp. 108-126.

Nielsen, J., Mathiassen, L. and Newell, S. (2014). Theorization and translation in information technology institutionalization: evidence from Danish home care. MIS Quarterly, vol. 38(1), pp. 165-186.

Nutley, S., Walter, I. and Davies, H. T. O. (2007). Using Evidence: How research can inform public services. Bristol: Policy Press.

Olsson, T. M. (2007). Reconstructing evidence-based practice: an investigation of three conceptualisations of EBP. Evidence \& Policy: A Journal of Research, Debate and Practice, vol. 3, pp. 271-285.

Otto, H.-U., Polutta, A. and Ziegler, H. (2009). Reflexive Professionalism as a Second Generation of Evidence-Based Practice: Some Considerations on the Special Issue "What Works? Modernizing the Knowledge-Base of Social Work. Research on Social Work Practice, vol. 19, pp. 472-478.

Rambøll. 2012. Afrapportering. Analyse af de økonomiske konsekvenser på området for udsatte børn og unge (Rapport til Social- og Integrationsministeriet). København: Rambøll.

Reiermann, J. and Andersen, T. K. (2015). Milliarder bliver brugt i blinde. Mandag Morgen.

Rieper, O., Hansen, H. F. (2007). Metodedebatten om evidens. København: AKF Forlaget.

Røvik, K. A. (2007). Trender og translasjoner, ideer som former det 21. århundrets organisasjon. Oslo: Universitetsforlaget.

Røvik, K. A. and Pettersen, H. M. (2014). Masterideer. In: K. A. Røvik, T. V. Eilertsen and E. M. Furu, ed., Reformideer i norsk skole: spredning, oversettelse og implementering, 1st ed. Oslo: Cappelen Damm Akademisk.

Sackett, D. L., Rosenberg, W. M. C., Gray, J. A. M., Haynes, R. B. and Richardson, W. S. (1996). Evidence based medicine: what it is and what it isn't. British Medical Journal, vol. 312, pp. 71-72.

Sahlin, K. and Wedlin, L. (2008). Circulating Ideas: Imitation, Translation and Editing. In: R. Greenwood, C. Oliver, K. Sahlin and R. Suddaby, ed., The SAGE Hand- 
book of Organizational Institutionalism. Los Angeles: Sage Publications, pp. 219-242.

Social- og Indenrigsministeriet. (2016a). Socialpolitisk redegørelse 2016. København: Social- og Indenrigsministeriet.

Social- og Indenrigsministeriet (2016b). Socialpolitisk Redegørelse: Viden og effekt skal forbedres. [online] Available at: http://sim.dk/nyheder/nyhedsarkiv/2016/jun/socialpolitisk-redegoerelse-videnog-effekt-skal-forbedres.aspx [Accessed 20 Jun. 2016].

Socialstyrelsen. (2013). Viden til gavn - politik for udvikling og anvendelse af evidens. København: Socialstyrelsen.

Svanevie, K. (2011). Evidensbaserat socialt arbete från idé till praktik. Umeå: Institutionen för socialt arbete, Umeå universitet.

Uddannelses- og Forskningsministeriet. (2012). Social indsats skal baseres på viden om hvad der virker. [online] Available at: http://ufm.dk/aktuelt/pressemeddelelser/2012/social-indsats-skal-baseres-paviden-om-hvad-der-virker [Accessed 5 Apr. 2017].

van der Zwet, R. J. M., Kolmer, D. M. B. and Schalk, R. (2016). Social Workers' Orientation Toward the Evidence-Based Practice Process: A Dutch Survey. Research on Social Work Practice, vol. 26, pp. 712-722.

Waeraas, A., Nielsen, J. A. (2016). Translation Theory "Translated": Three Perspectives on Translation in Organizational Research. International Journal of Management Reviews, vol. 236-270, pp. 236-270.

Walter, I., Nutley, S., Percy-Smith, J., McNeish, D. and Frost, S. (2004). Improving the use of research in social care practice, Knowledge Review. London: Social Care Institute for Excellence.

Wiis, J. (2015). Topleder i KL: Kommunerne skal turde at gå nye veje. DenOffentlige.dk, [online] Available at: http://denoffentlige.dk/topleder-i-kl-kommunerneskal-turde-gaa-nye-veje [Accessed 12 May 5 2015]. 
Bilag 1. Oversigt over interviewpersoner

\begin{tabular}{|c|c|c|}
\hline \multicolumn{2}{|c|}{ Navn } & tidligere stillinger \\
\hline 1 & $\begin{array}{l}\text { Nina Eg Han- } \\
\text { sen }\end{array}$ & $\begin{array}{l}\text { 2016-: Adm. Direktør, Socialforvaltningen, Københavns Kommune } \\
\text { 2015-2016: Afdelingschef, Social- og Indenrigsministeriet } \\
\text { 2012-2015: Direktør, Ministeriet for Børn, Ligestilling, Integration og } \\
\text { Sociale Forhold } \\
\text { 2010-2012: Børne- og kulturdirektør, Ringsted Kommune } \\
\text { 2005-2010: Kontorchef, Kontoret for Børn, Socialministeriet }\end{array}$ \\
\hline 2 & $\begin{array}{l}\text { Cathrine Lind- } \\
\text { berg Bak }\end{array}$ & $\begin{array}{l}\text { 2016-: Vicedirektør, Socialstyrelsen } \\
\text { 2012-2016: Chef for Børne- og unge enheden, Socialstyrelsen } \\
\text { 2011-2012: Handicapchef, Servicestyrelsen (senere Socialstyrelsen) } \\
\text { 2007-2011: Business Manager, Rambøll Management Consulting }\end{array}$ \\
\hline 3 & Knud Aarup & $\begin{array}{l}\text { 2016-: Formand for Socialpolitisk Forening } \\
\text { 2015-: Uafhængig konsulent } \\
\text { 2012-2015: Direktør, Socialstyrelsen } \\
\text { 2006-2012: Direktør, Social og Beskæftigelse, Randers Kommune }\end{array}$ \\
\hline 4 & $\begin{array}{l}\text { Steffen Bohni } \\
\text { Nielsen }\end{array}$ & $\begin{array}{l}\text { 2015-: Adm. Direktør, Børn og Unge, Gribskov Kommune } \\
\text { 2014-2015: Vicedirektør, Socialstyrelsen } \\
\text { 2012-2014: Afdelingschef, Socialstyrelsen } \\
\text { 2009-2012: Direktør for evalueringsviden, Rambøll Management Consul- } \\
\text { ting }\end{array}$ \\
\hline 5 & Agi Csonka & $\begin{array}{l}\text { 2013-: Direktør, SFI, Det Nationale Forskningscenter for Velfærd } \\
\text { 2007-2013: Direktør, Danmarks Evalueringsinstitut (EVA) }\end{array}$ \\
\hline 6 & Mette Deding & $\begin{array}{l}\text { 2017-: Forskningschef, Afdelingen for udsatte børn, skole og uddannel- } \\
\text { se, SFI } \\
\text { 2015-2016: Afdelingsleder, Afdelingen for skole og uddannelse, SFI } \\
\text { 2012-2014: Afdelingsleder, Afdeling for kontrollerede forsøg, SFI } \\
\text { 2009-: Afdelingsleder, SFI Campbell }\end{array}$ \\
\hline 7 & $\begin{array}{l}\text { Merete Konne- } \\
\text { rup }\end{array}$ & $\begin{array}{l}\text { 2015-: Analysechef, TrygFonden } \\
\text { 2013-2015: Områdechef for trivsel, TrygFonden } \\
\text { 2013-: Medlem af Steering Committee, Campbell Collaboration } \\
\text { Knowledge Translation and Implementation Coordinating Group } \\
\text { 2011-2012: Seniorrådgiver, TrygFonden } \\
\text { 2005-2013: Co-chair, Campbell Collaboration Users Group, medlem af } \\
\text { Steering Group } \\
\text { 2002-2009: Direktør, Nordisk Campbell Center (senere SFI Campbell) }\end{array}$ \\
\hline 8 & $\begin{array}{l}\text { Niels Christian } \\
\text { Barkholt }\end{array}$ & $\begin{array}{l}\text { 2012-: Næstformand, Dansk Socialrådgiverforening } \\
\text { 2007-2014: Bestyrelsesmedlem, FORSA - foreningen for forskning og } \\
\text { udvikling i socialt arbejde } \\
\text { 2009-2012: Konsulent, Center for Børn \& Familie, Faxe Kommune }\end{array}$ \\
\hline 9 & Tina Wahl & $\begin{array}{l}\text { 2012-: Kontorchef, Center for Social og Sundhed, KL } \\
\text { 2006-2012: Chefkonsulent, Økonomiforvaltningen, Københavns Kom- } \\
\text { mune }\end{array}$ \\
\hline 10 & $\begin{array}{l}\text { Erik Kaastrup- } \\
\text { Hansen }\end{array}$ & $\begin{array}{l}\text { 2010-: Formand, Metodecenteret } \\
\text { 2008-: Direktør, Sociale Forhold og Beskæftigelse, Århus Kommune } \\
\text { 2006-: Hovedbestyrelsesmedlem, Socialchefforeningen (Foreningen af } \\
\text { Kommunale Social-, Sundheds- og Arbejdsmarkedschefer i Danmark) }\end{array}$ \\
\hline
\end{tabular}

